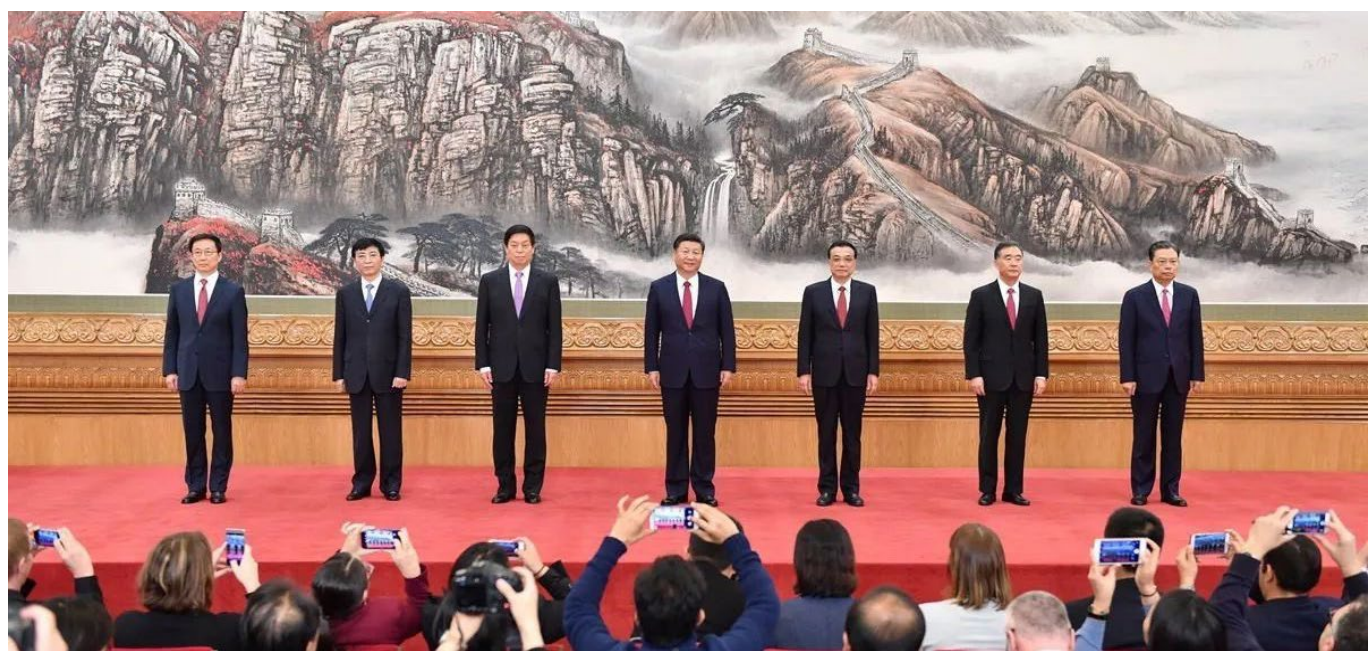

\section{Is the Sky Falling in on Women in China?}

\section{Robert WALKER \\ Jane MILLAR}

China has fallen to 106th place in World Economic Forum's Gender Gap Index for 2020. Drawing on recently-published research by Chinese scholars, this article explores whether this accurately reflects the status of women in contemporary China, concluding that China's progress towards gender equality has stalled in the face of the powerful combination of marketisation and patriarchy.
Standing Committee of the Central Political Bureau of the Communist Party of China, 2017. PC: Sohu.com. $\mathrm{f}$ women in China once held up half the sky, they no longer do. China has slipped again this year to 106th place in the World Economic Forum's Gender Gap Index (GGI), behind Brazil and Russia and just six places ahead of India. In 2006, China was placed $63 \mathrm{rd}$, albeit out 112 rather than 153 countries (WEF 2006, 2020). It is clearly important to understand the reasons behind this downward spiral.

\section{Progress with the People's Republic of China}

Mao Zedong's aphorism about women holding up half the sky may have been aspirational, and was certainly full of political 
intent, but the first 35 years of the People's Republic of China (PRC) brought great improvements for the status of women. Article 6 of China's Constitution prescribes that 'Women should enjoy equal rights with men in political, economic, cultural, educational and social life' and, nominally ending customary arranged marriages, that 'freedom of marriage for men and women shall be put into effect'. State-owned enterprises and, to a lesser extent, collective farms supported women's ability to work through the provision of childcare such that female labour participation rose rapidly and remained at 'saturation levels' for much of the period between 1958 and 1978. Moreover, although women have never achieved the pay parity promised by the first National People's Congress in 1954, women's incomes rose significantly relative to men's, reaching a high point of 84 percent in 1988 (Yang 2020).

However, it is important not to overstate the achievements of the early years of the PRC. China's official news agency, Xinhua, noted in 2009 that when Mao spoke his muchquoted words in 1968, the All-China Women's Federation had ceased to function because gender sameness was the goal, not gender equality: women were 'to be battle-dressed, and not rosy-gowned' (People's Daily 2009). But, even before the Cultural Revolution, there is evidence that, as Judith Stacey observed, 'the socialist revolution in China was patriarchal' replacing Confucian patriarchy 'first by new democratic patriarchy, and then by patriarchal socialism' (Stacey 1983, 253). The land reform movement reallocated land to men not to women, while Liu (2007) argues that the work unit (danwei单位), the workplace and source of wrap-around occupational welfare, created a Confucian-like family with the leadership as patriarchs. Women were multiply disadvantaged: less likely to be soldiers or graduates they had little chance of being promoted from worker (工人) to cadre (千部), and therefore they were weakly placed when it came to matchmaking, housing allocation, surveillance of family life, and family planning, all of which were responsibilities of the danwei leadership. It is against this backdrop that we need to assess claims that, while women's status advanced during the first 35 years of the PRC, it has stalled and may, in some respects, have regressed since the onset of the reforms.

\section{Casualties of Economic Reform}

Evidence that women's progress, both absolute and relative, has indeed stalled since the reform and opening up of the economy initiated by Deng Xiaoping in the late 1970s is provided in 12 articles by 20 Chinese scholars published in the latest issue of the academic journal Social Inclusion. China's falling place in the GGI provides a starting point, but there are good reasons why the GGI might not flatter China. The sex ratio at birth, for example, is effectively counted twice and China's imbalanced sex ratio is the worst in the world with 115 boys being born for every 100 girls. Nevertheless, Chen Binli and He Hailan (2020) reveal that the fall in China's position in the world league table cannot simply be explained by this or by the addition of new countries. Whereas countries overall have improved significantly with respect to three of the four indicators included in the GGI-economic participation and opportunity, educational attainment, and political empowermentChina's progress has not kept pace.

It is important not to overlook the fact that, since the GGI was introduced in 2006, China's per capita gross domestic product has increased by over 465 percent and poverty measured at 1.90 USD/day has fallen from about 18 percent to much less than 1 percent. Nevertheless, men seem to have benefitted more than women from China's economic miracle as the logic of the marketplace has placed women at a growing disadvantage. For instance, Yang Juhua (2020) shows that over this period women's wages fell from 79 percent to just 65 percent as a 

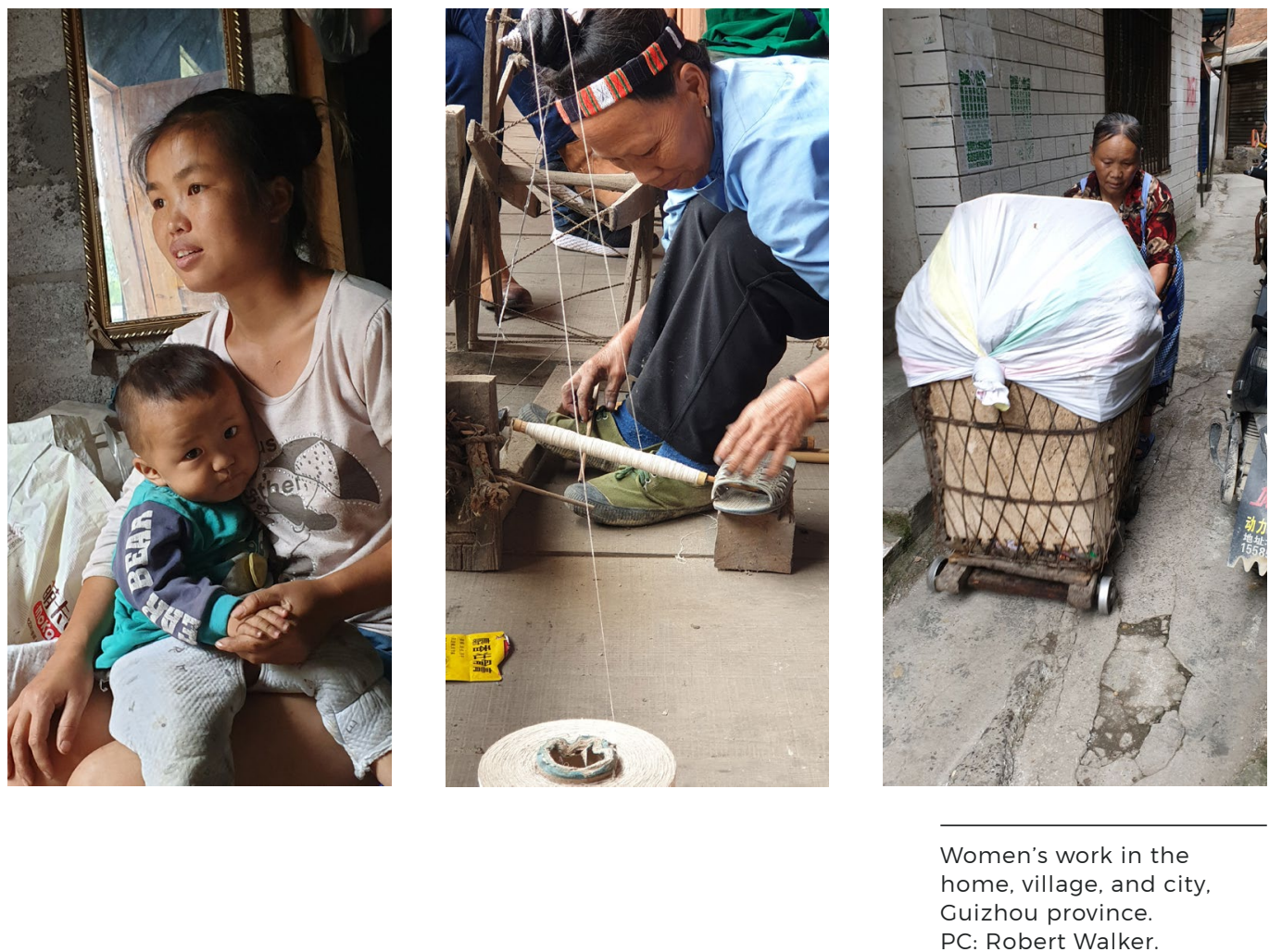

proportion of men's at a time when women's level of educational attainment was growing much faster than men's.

Processes increasing gender inequality began in the early 1980s with the 'return home' (回 家) movement designed to create employment opportunities for young people returning from the countryside, where they had been sent during the Cultural Revolution. There then followed the closure of many danwei in the 1990s which employed disproportionate numbers of women who, evidence suggests, lost their jobs first because of their low status, lack of connections, and willingness not to create 'trouble', or, perhaps, their inability to do so given their weak position (Wang 2003). More recently, the emphasis on profit maximisation, which fails to value non-marketable care and children, is deterring employers from hiring and promoting women, a trend ironically exacerbated by improved maternity benefits designed to encourage women into work (Xi 2019). The current female labour force participation rate, 61 percent in 2019, is only two-thirds of what it was in the 1960s (Bauer et al. 1992).

\section{The Power of Patriarchy}

However, to focus exclusively on the economy is to neglect the persistent power of patriarchy. China's economic growth since opening up has been fuelled by the largest rural-urban migration in history. In accordance with the traditional maxim that 'the man dominates outside, and the woman dominates inside（男主 外, 女主内), the first wave of migration in the 1980s saw men leaving women behind to care 


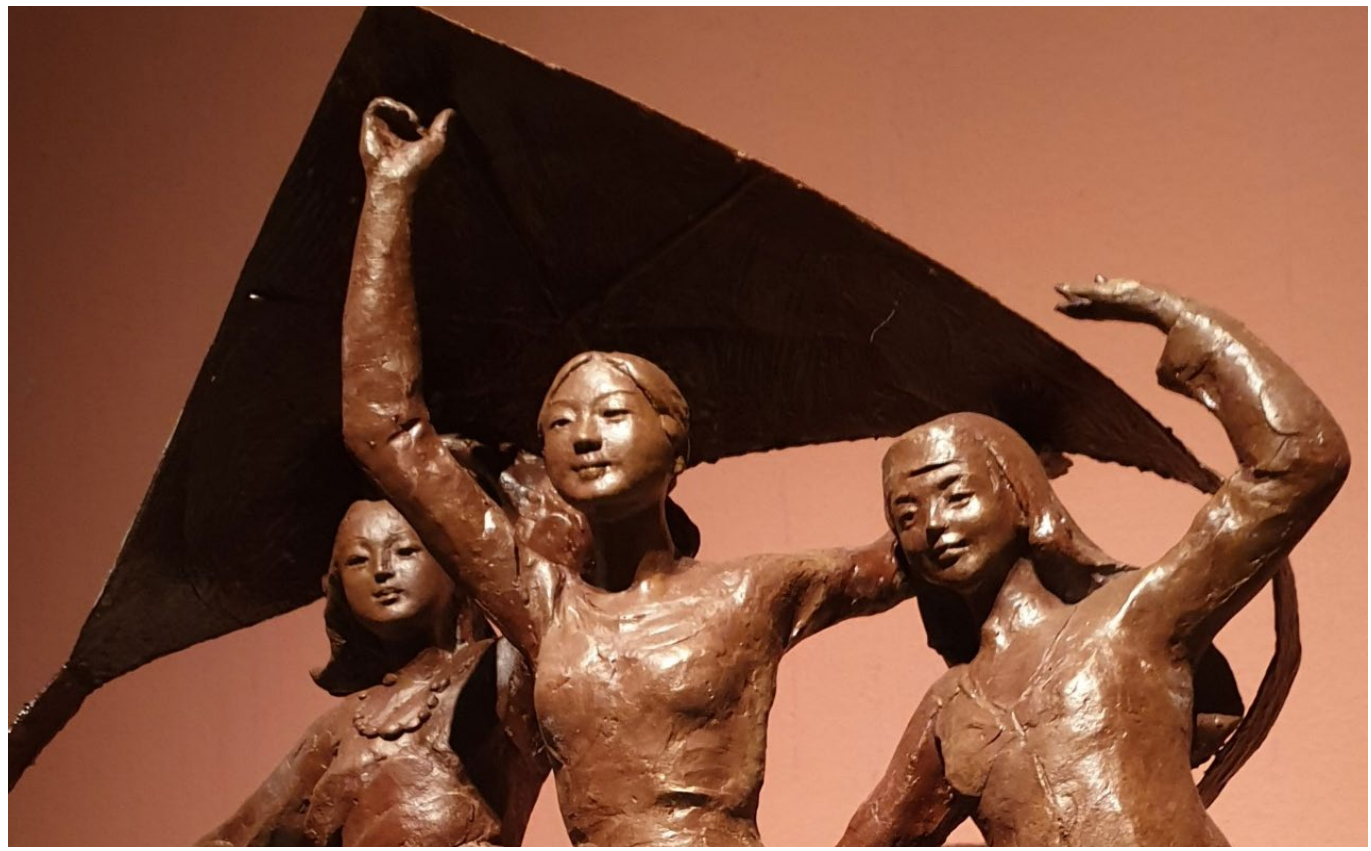

Qing Chun, Pursuing

Dreams, Beijing's National Museum of Art, 2018.

PC: Robert Walker.

for farms and children. A decade or so later the second wave comprised younger unmarried men and women, and therefore appeared to have the potential to break the shackles of patriarchy, family, and place. Ethnographies in the Social Inclusion special issue show that this was not to be.

Young women initially enjoyed the freedom engendered by higher urban wages together with the possibility of meeting and marrying someone of their choice. Moreover, with the younger generation earning urban wages and thereby contributing the larger share of income to the extended family, this frequently meant a shift in influence away from the parental generation (Yang and Ren 2020). However, limited qualifications trapped most young women migrants in informal or routine factory work that offered few prospects and incomes that merely replaced absolute poverty with relative poverty (Zhang 2020). For a small minority, prostitution, the life of a xiaojie (小 姐), appeared preferable to the exploitation of factory work, enabling them to identify with a portfolio of roles-singer, dancer, confident, networker, and businesswomanthat seemed modern and to speak of agency and independence (Ding 2020). But all women migrants risked innuendo as to their motives as unmarried young women living away from home, and sexual harassment and worse from employers and other men at work. Vietnamese migrants arriving in the Sino-Vietnamese borderlands defined by the Nanning-the Friendship Port-Hanoi economic corridor saw marriage to a Chinese man as protection against such abuse, as freedom from the restrictions of the village, and as a route to relative prosperity (Huang 2020). 
However, for most Chinese migrants a permanent life in the city is impossible without a graduate education. Attachment to the village is enforced by the household registration system (hukou 户口), which denies migrants permanent residence in the city and limits their ability to access welfare services to the place of their birth. On marriage, men's jobs are prioritised, not always for economic reasons since female migrants can often earn more working on assembly lines than men can earn through manual labour. That said, the continued preference for sons over daughters, attested to by the heavily skewed sex ratio at birth, means that it is not uncommon for women to have forsaken education to support the progress of their brothers, thereby weakening their position in the labour market and in marriage (Fan and Chen 2020). Lone daughters, in contrast, may be treated like sons, pushed to succeed educationally only then to be expected to make a suitable match and behave as the dutiful wife. Moreover, while such traditional patriarchal values may be more prevalent in rural areas and among working class and rural migrants, they are also evident among China's elite. Tu Mengwei and Xie Kailing (2020) interviewed 'privileged daughters' living abroad in the United Kingdom and found that their parents assessed success in terms of their daughters achieving a good marriage, and were fearful that academic prowess and financial independence would prevent this since the conventional pattern is for Chinese males to marry their social inferiors. Marriage, too, is a powerful predictor of when women withdraw from the labour market, women care for the home while men work outside (Xi 2019).

\section{Women Lacking Power}

To turn again to rural-urban migrants, women are likely to return to the village with the arrival of children, more typically on the birth of a second child since grandparents are generally thought able to look after one child left behind in the village. However, for most women this is not a return to their own village. Because of the principle of patrilocality, living with or close to the husband's family generally still prevails. As outsiders in their husbands' village and without the protection of a local hukou, migrant wives are vulnerable to exploitation and often carry heavy burdens: working the land, caring for children, picking up casual employment, and frequently providing domestic services and personal care at the beck and call of their in-laws. Zhang Guanli (2020) finds, moreover, that they never manage to cast off the stigma of being an outsider or that of the poverty that caused them to migrate to a more prosperous province. Yang Lichao and Ren Xiaodong (2020) confirm this, but further find that even women migrants who return to their own village in Shanxi province, either still single or having married locally, find little recognition of the skills or experience that they have acquired as migrants. As many as 40 percent of returnees said that they would like to be involved in village governance but the response of one village head was typical:

\section{Young women are more capable than the older generations. But it is a rule for women to stay inside to look after the family and men work outside to deal with big issues. It also works in village governance (Cited in Yang and Ren 2020).}

Such views may help to explain why just 6 percent of village heads are women and, in microcosm, hint at why only 8 percent of the membership of the Central Committee of the Communist Party of China, the most powerful political body, are female. There is public recognition of this deficiency, with both the China Women's Development Outline (201120) and the National Human Rights Action Plan (2016-20) calling for increased representation of women, an aspiration enshrined in election law. However, there appears to be much tokenism-with women on the leadership teams of 90 percent of the provinces and municipalities and 88 percent of the counties 
but not in large numbers-and little consistent improvement, certainly relative to other countries. In 2020, China ranked 95th on the political empowerment component of the GGI compared to 52nd in 2006.

\section{A Corrupted Ideal}

Overall, the evidence assembled by the scholars writing in Social Inclusion suggests that the distinguishing feature of China's market socialism is perhaps its fusion with patriarchal socialism-the government continues to know what is best. By focussing on economic growth and the maximisation of marketable wealth, and with women effectively excluded from political decisions that matter, the PRC's founding ideological commitment to gender equality has become corrupted and, as Yang Juhua (2020) concludes, 'conditional on the premise of not harming the interests of men'. For women to hold up half the sky, they need an equal share of power. But in China, that seems still to be a very long way off. 
This text is taken from Made in China Journal: Volume 5, Issue 1, 2020, edited by Ivan Franceschini, Nicholas Loubere and Christian Sorace, published 2020 by ANU Press, The Australian National University, Canberra, Australia.

doi.org/10.22459/MIC.05.01.2020.06 